\title{
Specyfika rękopiśmiennego obiegu literatury w XVI-XVIII wieku
}

Janusz Maciejewski 


\section{Janusz Maciejewski}

\section{Specyfika rękopiśmiennego obiegu literatury w XVI-XVIII wieku}

$\mathrm{O}$ tym, że literatura staropolska zachowała się w dużej części w postaci rękopiśmiennej, wiadomo powszechnie. Dawno też doceniono rolę manuskryptu w dochowaniu do naszych czasów takich arcydzieł jak Lutnia i Kanikuła Jana Andrzeja Morsztyna, Wojna chocimska Wacława Potockiego, wiersze Daniela Naborowskiego, Stanisława Herakliusza Lubomirskiego i wielu innych wybitnych pisarzy. Ale jego znaczenie rozumiano głównie w aspekcie utrwalenia i przechowania utworu - który, nie zapisany, skazany bylby zapewne na zatracenie - a więc w pewnym sensie biernie i statycznie. Nie brano na ogół pod uwagę jego ówczesnego oddziaływania, wyłączono go z bieżącego życia literackiego. Traktowano także utwory pozostające $\mathrm{w}$ rękopisie jako swoisty margines literatury drukowanej, etap wstępny publikacji z takich czy innych powodów niezrealizowanej. Nie uświadamiano sobie autonomiczności i niezależności obiegu rękopiśmiennego, a i samo przekonanie, iż był taki obieg, dopiero w ostatnich latach znalazło miejsce w świadomości badaczy (będzie o nich mowa nizej). Cały obszar kultury związanej z rękopisem, jego czytelniczą egzystencją i oddziaływaniem, zostal całkowicie przesłonięty wynalazkiem druku w polowie XV wieku, rozumianym jako absolutna rewolucja, która otworzyła nie tylko zupełnie nowy, ale zarazem powszechny (czy prawie powszechny) zwyczaj przekazywania sobie informacji za pomoca pisma (odtąd, jeśli nie wyłącznie, to przeważnie drukowanego).

Otóż przekonanie takie dalekie jest od ścisłości. Wynalazek Gutenberga nie od razu bowiem stał się dobrem powszechnym. Przede wszystkim przez długi czas był dość kosztowny, a więc i dostępny stosunkowo niewielkiej grupie ludzi. Choćby z tego powodu nie usunąl też natychmiast innych środków utrwalania i rozpowszechniania tekstów - zarówno literackich, jak politycznych, informacyjnych, a nawet naukowych. Ale, po drugie, nie uczynił 
tego także dlatego, że zastał już istniejące - i to stosunkowo świeżej daty, a więc prężne i w pelni rozwoju - inne sposoby rozpowszechniania pism. WXV wieku istniał juz sprawnie funkcjonujący obieg tekstów poprzez ręczne odpisywanie i rozpowszechnianie w ramach kontaktów międzyludzkich różnego typu, które nawet z czasem uległy instytucjonalizacji. Jak stwierdziłem wyżej, wspomniane rękopiśmienne sposoby obiegu literackiego pojawily się niezbyt długo przed wynalazkiem Gutenberga, początkowo rozszerzały się i doskonaliły równocześnie $z$ rozszerzaniem się i doskonaleniem druku.

Oba zresztą związane były $z$ inną, nie mniej ważną od dzieła niemieckiego złotnika, rewolucją w zakresie technicznych podstaw kultury. Stało się nią wynalezienie papieru. Dokonano tego w dalekich Chinach jeszcze w II wieku naszej ery, ale długi czas byl on znany tylko w krajach Dalekiego Wschodu. Przez Samarkandę (VII w.) i arabski Bliski Wschód (X w.) dotarł on w polowie XII stulecia do muzułmańskiej Hiszpanii, stamtąd w XIII w. do Wloch, a w XIV do Niemiec i reszty Europy ${ }^{1}$. Na ziemiach polskich papier (początkowo sprowadzany z Włoch, Francji i Niemiec) pojawił się w II połowie XIV w. W następnym stuleciu powstały u nas pierwsze papiernie (najpierw w 1473 r. w Gdańsku, potem we Wroclawiu i Krakowie) ${ }^{2}$.

Wprowadzenie papieru jako materiału piśmiennego stało się bardzo ważnym wydarzeniem w dziejach kultury, w niewielkim stopniu uświadamianym przez historyków, gdyż zostało ono przesłonięte wynalazkiem druku. Przede wszystkim w najprostszym sensie ilościowym. Do tej pory materiałem, na którym pisano i z którego sporządzano księgi, był pergamin — produkowany ze skór zwierzęcych, rzadki więc i trudno dostępny dla potencjalnego użytkownika. Wcześniej, w antycznej Grecji i Rzymie, posługiwano się także papirusem, wytwarzanym z rosnącej nad Nilem rośliny o tej samej nazwie. Był on tańszy i praktyczniejszy. W średniowiecznej chrześcijańskiej Europie stał się on jednak niedostępny z powodu odcięcia jej od Egiptu przez muzułmańskich Arabów. Utrzymanie pergaminu jako jedynego materiału piśmiennego uniemożliwiało szybkie i latwe powielanie tekstów i wykluczyłoby w ogóle sensowność wynalazku Gutenberga.

Sytuacja diametralnie się zmieniła, odkąd zaczęły w Europie pracować tzw. młyny papiernicze. We Włoszech działały od XIII w. (w Niemczech pierwszy powstał w $1390 \mathrm{r}$.) ${ }^{3}$. Wprowadzono przy tym od razu udoskonalenie: w Chinach i w krajach muzułmańskich papier robiono $z$ bawełny, rzadkiej w średniowiecznej Europie. Tu zorientowano się szybko, że równie dobrze wyrabia się on $z \operatorname{lnu}$ i konopi, a ściślej mówiąc, ze stworzonego $z$ nich płótna. Za materiał do wyrobu papieru zaczęły więc służyć szmaty i wszelkiego typu odpady tekstylne, a więc surowiec niezwykle tani. Tanim stał się zatem również sam papier. Podstawowy material piśmienny przestal być luksusem.

\footnotetext{
1 Zob. W. Sandermann, Die Kulturgeschichte des Papiers, Berlin-Heidelberg 1988, s. 79 i nast.

2 Zob. Z. Węglowski, K. Przezdziecka, Papyros. Dzieje pewnego wynalazku, Warszawa 1986, s. 30.

${ }^{3}$ Zob W. Sandermann, op. cit., s. 80.
} 
Powstały więc przesłanki nie tylko do wynalazku druku, ale i do tworzenia się wcześniej i później innych form piśmiennego obiegu literackiego. I takie formy powstały. Był to obieg tekstów odpisywanych ręcznie, przekazywanych lub sprzedawanych innym. Zaczął się on wykształcać w XV wieku, doskonalił się w XVI i XVII, a istniał jeszcze w XVIII stuleciu. Dopiero u jego schyłku ustąpił calkowicie obiegowi słowa drukowanego.

Aby mógł rękopiśmienny obieg literatury powstać, musiało jednak być spełnionych jeszcze kilka innych warunków. Przede wszystkim musiała się rozszerzyć wśród ludności oświata, umiejętność sztuki pisania i czytania. W średniowieczu pod tym względem było źle. Analfabetyzm obejmował nie tylko lud, ale także rycerstwo i większość mieszczaństwa. Piśmienni byli tylko duchowni, szczyty arystokracji, wielcy kupcy. Dlatego - jeśli chodzi o twórczość w językach narodowych - panowal typ kultury oralnej. Tekstów uczono się na pamięć, rozprzestrzeniali je trubadurzy i minnesängerzy ${ }^{4}$. U schyłku średniowiecza ustny obieg utworów zaczyna ustępować miejsca pisemnemu, a ich rozprzestrzenianiu służą początkowo nie tyle drukowane książki, ile właśnie rękopisy. Wszystko to jednak może nastąpić dzięki rozwojowi oświaty, dzięki temu, że nie wyizolowane jednostki, ale — stopniowo górne warstwy narodu w całości zaczynają posiadać sztukę czytania i pisania.

W XV, a zwłaszcza w XVI wieku następuje w tym zakresie wyraźny skok. Ambicje władania piórem zaczyna mieć bogatsze mieszczaństwo, większość szlachty. Widzi w nim szansę awansu wielu plebejuszy. Tendencja ta ugruntuje się w XVII stuleciu, zwłaszcza dzięki oświatowej działalności zakonów, głównie jezuitów.

To był pierwszy dodatkowy warunek powstania rękopiśmiennego obiegu literatury (zresztą również obiegu drukowanego). Drugim był rozwój i doskonalenie form komunikacji międzyludzkiej. Jak ona wyglądała? Jej podstawowym czynnikiem byli ludzie podróżujący, zwłaszcza podróżujący wielokrotnie, niejako zawodowo. Należały do nich na przykład takie grupy wędrowne jak czeladnicy czy - szczególnie - studenci. Na dworach władców i możnych utrzymywano również specjalnych gońców (niekiedy do kilkudziesięciu), używanych do różnego rodzaju przekazywania informacji, korespondencji. Spełniali oni nawet mniejszej rangi poselstwa. Wszyscy zaś przewozili również utwory literackie. Oni także oraz ci, którym te teksty przekazywali - odpisywali je i dalej rozpowszechniali. Oczywiście powielano literaturę — jeśli się podobała — również na miejscu, zwłaszcza w większych skupiskach ludzi (dwory, miasta).

Z czasem zaczęły powstawać stale formy komunikacji na pewnych szlakach. Pojawily się „firmy” zajmujące się utrzymaniem regularnie kursujących pojazdów, które zabierały za opłatą podróżnych i oczywiście korespondencję bądź inne przesyłki. W XVI wieku zamieniają się one w stałą instytucję — pocztę - początkowo na pewnych trasach kierowaną, za

\footnotetext{
+ Na temat kultury oralnej w Polsce średniowiecznej pisze Teresa Michalowska: Średniowiecze, Warszawa 1995, s. 336-340, oraz Juliusz Nowak-Dluzewski w: Okolicznościowa poezja polityczna w Polsce. Średniowiecze, Warszawa 1963, s. 15-19 (tu także na s. 6 cytaty z niemieckiego badacza Rocha von Liliencrona i francuskiego Karola Lenienta, dotyczące analogicznych zjawisk w Zachodniej Europie).
} 
przywilejem władców, przez osoby prywatne (przykładowo w Polsce linia Kraków-Wenecja przez Montelupich), z czasem całkowicie państwową. W Polsce poczta zaczęla działać także w XVI wieku. Za jej początek przyjmuje się otwarcie stalej linii do Wloch w 1558 roku $^{5}$. Powstanie poczty niesłychanie ułatwiło pisemne kontakty międzyludzkie. Nie trzeba było już wysylać listów przez specjalnych posłańców bądź gołębie pocztowe. A przy okazji zintensyfikowało obieg literacki. Bo nie tylko listy byly rozprowadzane przy jej pomocy, ale także utwory literackie - często zresztą jako załączniki do tychże listów.

Poczta w dawnych wiekach — jak wiadomo — slużyła nie tylko korespondencji, ale także podróżowaniu (jemu nawet przede wszystkim). Obie swoje funkcje rozwijała i rozszerzala przez wiek XVII. W następnym stuleciu sieć stalych linii dylizansów pocztowych pokryla gęsto całą Europę. Wówczas zresztą zaczęła ona spełniać także niezwykle ważną rolę właśnie w obiegu rękopisów literackich i publicystyczno-informacyjnych.

Zanim do tego przejdę, jeszcze chciałbym wspomnieć o ostatnim warunku ułatwiającym rękopiśmienny obieg literacki w Polsce (w danym wypadku zresztą dotyczącym wyłącznie naszego kraju). Myślę o ustroju parlamentarnej demokracji szlacheckiej. Ustrój ten narzucał sporą ruchliwość stanu panującego. Częste wyjazdy na sejmiki, sejmy, elekcje, trybunały, konfederacje, na dwory magnackie, gromadzące stale bądź okresowo tlumy szlachty, sprzyjały wymianie informacji, a także tekstów literackich. Sprzyjało temu i bogate życie towarzyskie szlachty polskiej oraz upodobanie do dalekich nieraz wyjazdów w odwiedziny. Rozczłonkowanie po całym kraju wielkich latyfundiów wytwarzało potrzebę okresowego przenoszenia się dworów magnackich do różnych rejonów Rzeczypospolitej. Wszystko to generowało zarówno samo powstawanie literatury, zwłaszcza okolicznościowo-politycznej, jak i ułatwiato jej krążenie i rozpowszechnianie.

W polskiej tradycji historycznoliterackiej — jak stwierdziłem to na początku tego szkicu —za "stulecie rękopisów” uznano wiek XVII, przeciwstawiając go okresowi renesansu, kiedy to „niemal wszyscy pisarze ubiegali się o druk swych utworów”. . Nie jest to ścisłe. To prawda: w czasach zygmuntowsko-batoriańskich procentowo więcej pisarzy wydawało swe dzieła drukiem. Ale po pierwsze nie wszyscy. Po drugie, czynili to na ogół - jak na przykład Kochanowski - po uprzednim dłuższym lub krótszym krążeniu utworów w obiegu rękopiśmiennym. Po trzecie wreszcie, ten ostatni nie narodził się ani w XVII, ani w XVI wieku, lecz istniał gotowy już wcześniej, zanim druk wynaleziono, i nie przerwał ani na chwilę swego funkcjonowania po jego wprowadzeniu, ale caly czas był czynny obok obiegu pism drukowanych na niemalże takich samych prawach. Bardzo wyraźnie — jeśli chodzi o wiek XVII

\footnotetext{
${ }^{5}$ Zob. F. Jakubowski, Poczta polska od czasów najdawniejszych do pierwszej wojny ślviatowej, w: 400 lat poczty polskiej, Warszawa 1958, s. 13-160; Z Borcz, Polskie poczty, Wrocław 1992, s. 16-41.

6 Staropolska kultura rękopisu, red. H. Dziechcińska, Warszawa 1990, s. 5.
} 
- stwierdza to Joanna Partyka w swej książce o sylwach szlacheckich ${ }^{7}$ czy Krzysztof Mrowcewicz w Drukarzu $w$ wirydarzu ${ }^{8}$. Ale obserwacja ta jest prawomocna i wcześniej, w równym stopniu może dotyczyć rzeczywistości XVI wieku. Albowiem, jak pisze Krzysztof Dmitruk,

Wydarzeniowa historia staropolszczyzny jest właściwie mozaiką współistniejących tendencji i zaskakujących nawrotów. Najlepszym dowodem tego stanu rzeczy może być wysoka pozycja przekazu rękopiśmiennego. Wynalazek druku (...) nie doprowadzil do poniechania tradycyjnych obiegów sztuki słowa9 9

Z tym, że nie był on - myślę o obiegu rękopiśmiennym - tak bardzo tradycyjny. Również powstał dopiero po wprowadzeniu do użytku papieru i rozszerzeniu się oświaty, a więc na bardzo krótko przed wynalazkiem Gutenberga.

Niewiele wiemy o tym, jak wyglądał obieg rękopiśmienny u swych początków. Możemy się tylko domyślać, że nośnikiem tekstu były luźne karty papieru wypełnione przez autora, a następnie powielane poprzez odpisywanie. Wszystko wskazuje też, że już wtedy istniał zwyczaj zatrudniania skrybów przygotowujących pewną ilość egzemplarzy utworu, rozprowadzanych następnie (odpłatnie lub nie) wśród chętnych lektury. W podobny sposób zapewne rozchodziły się takie utwory jak na przykład paszkwil Erazma Ciołka na małzeństwo Władysława Jagiełly z Elżbietą Granowską czy Jędrzeja Gałki z Dobczyna Pieśn o Wiklefie ${ }^{10}$. Utwory owe i reakcja na nie są zarazem świadectwem tego, że w XV wieku istniał już rozwinięty obieg rękopiśmienny i rynek czytelniczy.

Znacznie więcej możemy powiedzieć o XVI stuleciu, z którego mamy ewidentne dowody, iż istniało życie literackie oparte na rękopiśmiennym obiegu utworów. Wiemy na przykład, że sława Jana Kochanowskiego jako autora fraszek na kilkadziesiąt lat wyprzedziła ich opublikowanie w 1584 roku, skoro już Eukasz Górnicki w wydanym w 1566 roku Dworzaninie polskim przywoluje je jako czytywane, popularne utwory ${ }^{11}$. Tenże Kochanowski we fraszce Do Stanistawa Porębskiego (II 57) wymienia adresata wiersza jako autora cenionych przez siebie Skotopasek - a więc utworu krążącego zapewne tylko w odpisach, skoro nic nie wiemy o jego druku (nie dochował się zresztą do naszych czasów) ${ }^{12}$. Z różnych świadectw wiemy, że sławny był jako poeta jeszcze za swego życia Mikolaj Sęp Szarzyński, choć Rytmy abo wiersze polskie wyszły dopiero dwadzieścia lat po jego śmierci ${ }^{13}$. Nie publikowal drukiem

7 Zob. J. Partyka, Rękopisy dwoni szlacheckiego doby' staropolskiej, Warszawa 1995, s. 8, 25-26.

${ }^{8}$ Zob. K. Mrowcewicz, Drukarz w wirydarzu, czyli co pisali autorzy staropolskich rękopisów o swoich wierszach, w: Staropolska kultura rękopisu..., s. 7.

${ }^{9}$ K. Dmitruk, Galaktyka kultury, w: Kultura żywego stowa w dawnej Polsce, red. H. Dziechcińska, Warszawa 1989, s. 16.

${ }^{10}$ J. Nowak-Dlużewski, op. cit., s. 56-68.

1 Zob. Ł. Górnicki, Dworzanin polski, opr. R. Pollak, Warszawa 1950, s. 131.

12 Zob. J. Kochanowski, Fraszki, opr. J. Pelc, Wroclaw 1991 (BN I 163), s. 78.

${ }^{13}$ Najstarszy znany przekaz dowodzący tego pochodzi z 1583 roku, a zamieszczony jest przez Antonina z Przemyśla w dedykacji (dla Katarzyny Wapowskiej z Maciejowa) poprzedzającej przekład Różańca... Ludwika z Granady. W roku następnym wymienia go Bartlomiej Paprocki w Herbach rycerstwa polskiego we 
swoich utworów Jan Smolik. Rękopiśmienny tylko obieg miała w większości okolicznościowa poezja polityczna, już dość bogata w tym stuleciu ${ }^{14}$. Nie był więc wiek XVI tak skrajnym przeciwieństwem następnego stulecia, jakby to wynikało z cytowanego wyżej zdania Hanny Dziechcińskiej. Nie był też nowością w czasach baroku rękopiśmienny — obok drukowanego - obieg literatury, bo istniał on od schyłku średniowiecza, odkąd tylko umożliwiało go wprowadzenie papieru jako materialu piśmiennego i rozwój oświaty sprawiający, że mogły $z$ niego korzystać większe grupy ówczesnego społeczeństwa.

Stwierdzenie to nie oznacza jednak, iż nie widzę odmienności sarmackiej formacji kulturowej od renesansowej właśnie w omawianej tu dziedzinie. Różnice między nimi dały przy tym o sobie znać na różnych polach, na które chciałbym zwrócić teraz uwagę.

Przede wszystkim widać je w zakresie czysto ilościowym. Rozszerzenie się oświaty i rozwój demokracji szlacheckiej, włączającej w aktywne życie publiczne cały, bardzo liczny, stan szlachecki, sprawiły, że wzrasta ilość zarówno drukowanych książek, jak i krążących między ludźmi rękopisów, że znacznie więcej twórców pisało do dużo szerszego grona odbiorców. Przy czym rozwój obu obiegów był nierównomierny. Obieg rękopiśmienny szybciej się rozwijal niż drukowany. Stąd notabene dostrzegana przez badaczy jego przewaga i odbierane przez nich wrażenie, że dopiero teraz na dobrą sprawę pojawily się w kulturze polskiej rękopisy. Obieg tych ostatnich, rozwijając się i wzbogacając dalej w XVII iXVIII wieku, ujawniał zarazem dość duże wewnętrzne zróżnicowanie, niewidoczne jeszcze $\mathrm{w}$ dobie renesansu.

Z grubsza rzecz biorąc, w tym okresie daje się wyróżnić dwie zasadnicze formy obiegu rękopiśmiennego, które można by nazwać bezpośrednią i pośrednią. Pierwsza polegała na przekazywaniu sobie tekstów przez ludzi w kontaktach człowiek-czlowiek, bez dodatkowego pośrednictwa instytucji; drugi - właśnie poprzez instytucje (a więc zbliżony do obiegu pism drukowanych). Jeśli chodzi o pierwszy, można go podzielić na trzy modele obiegu, licząc od stosunkowo kameralnych do ogólnokrajowych.

Najmniejszy zasięg miał obieg, który można by nazwać rodzinnym. Reprezentowały go na przykład pamiętniki, wiersze okolicznościowe zapisywane w sylwach z okazji różnych wydarzeń domowych, same wreszcie ,silvae rerum" jako całość (choć do nich bywały wpisywane również utwory mające bardzo szeroki odbiór). Obieg rodzinny nie znaczyl przy tym „prywatny” - co bardzo mocno chcę podkreślić. Zgadzam się z Krzysztofem Mrowcewiczem, który twierdzil, że przedstawiciele polskiego baroku nie pisali „do szuflady”,

fragmencie poświęconym Stanislawowi Strusowi, „który na Rustawicy z nieprzyjacioły długo i mężnie czyniąc, zabit. Co ten wiersz Mikołaja Sępa z domu Junosza, młodzieńca uczonego opowiada tymi słowy..." (dalej następuje tekst wiersza). Cyt. za wydaniem Turowskiego, Kraków 1858, s. 686-687. O popularności poety za jego życia pisze wreszcie brat we wstępie do wydawanych przez siebie Rytmów abo wierszy polskich z 1601 roku.

${ }^{14}$ Zob. J. Nowak-Dłużewski, Okolicznościowa poezja polityczna w Polsce. Czasy zygmuntowskie, Warszawa 1966. 
choć niejednego historyka uwiodła poręczność gotowego idiomu, który jednak raczej zaciemnia niż wyjaśnia istotę zjawiska ${ }^{15}$.

Nie tworzył „do szuflady” pamiętników Jan Chryzostom Pasek, ale adresował je do swych pasierbów, ich dzieci, wnuków, innych krewnych. Dla rodziny były przeznaczone domowe sylwy, czasem zresztą wielopokoleniowe. Oczywiście także dla sąsiadów, znajomych - ale to już w dalszej kolejności.

Ten rodzaj obiegów gęsto pokrył obszar Rzeczypospolitej, ale zasięg każdego z nich był ograniczony: czytelników tekstu bezpośrednio po jego napisaniu było kilku bądź kilkunastu, i dopiero w wieloletniej perspektywie czasowej liczba ich się zwiększała. Nieco szerszy, jeśli chodzi o skalę czytelnictwa, był model drugi, który obejmował skupiska ludzkie liczące po kilkadziesiąt bądź kilkaset osób. Miał on zresztą dwie odmiany, które można by określić terminami dworskiego i sąsiedzkiego.

Model dworski był najlepiej realizowany przez twórczość Jana Andrzeja Morsztyna, kierowaną przede wszystkim do tych, których gromadził dwór królewski. Do nich adresował pięknie wykaligrafowane przez najętych zapewne skrybów egzemplarze Lutni i Kanikuty... Były one czytane, pożyczane sobie. Może sprzedawane i kupowane, bo przecież handel księgarski wówczas obejmował zarówno druki, jak i rękopisy. $\mathrm{Na}$ pewno zaś odpisywano z nich ciekawsze utwory, a może nawet przepisywano w całości. Dworski — choć nie królewski, ale magnacki - obieg miała także twórczość Daniela Naborowskiego, Olbrychta Karmanowskiego, a z piszących arystokratów - Stanisława Herakliusza Lubomirskiego.

Podobny ilościowo krąg odbiorców miała druga odmiana omawianego tu obiegu: sąsiedzka. Najlepszym jej przykładem jest rozpowszechniana w rękopisach twórczość Wacława Potockiego. Siedział on na wsi, ale miał — jak każdy szlachcic — bliskie kontakty towarzyskie z sąsiadami. Do nich przede wszystkim adresowal Moralia czy Ogród fraszek, wśród nich one krążyły, były odpisywane, zyskiwały pochwałę bądź krytykę.

Kolejny, trzeci (bądź - licząc dwie odmiany poprzedniego - czwarty) obieg można by nazwać stanowym. Utwory tego obiegu były adresowane do całej szlachty. Dominowała w nim wprawdzie nie literatura, ale publicystyka bądź wręcz dokumenty: manifesty, rezolucje, mowy sejmowe. Często zresztą były one odpisywane z druków, co świadczyło, że wciąż taniej było tekst przepisać, niż kupić wydrukowany. W każdym razie liczba odbiorców szła $\mathrm{w}$ tym obiegu w tysiące, skoro do dnia dzisiejszego mamy w zachowanych zbiorach pochodzących z najróżniejszych rejonów Rzeczypospolitej — po kilkaset przekazów tej samej mowy, listu, uchwały, ale i wiersza, poematu, obrazka prozatorskiego, a nawet niekiedy wieloaktowego dramatu (tak jest na przykład $z$ dwoma niezwykle popularnymi komediami z czasów konfederacji barskiej: Perekińczyk oraz Cnota uciemiężona, wolność obarczona czy z wywodzącą się jeszcze ze schyłku czasów saskich Łysą radą kolbuszowskq̨...). Jeśli chodzi

${ }^{15}$ K. Mrowcewicz, op. cit., s. 7. 
o literaturę krążącą w tym obiegu, to była ona prawie wyłącznie polityczna, najczęściej okolicznościowo-polityczna. Ta ostatnia $z$ reguły anonimowa.

Jak wyglądał sposób rozprzestrzeniania się tej literatury? Następował on najczęściej $z$ okazji różnego typu zjazdów: konfederacji, sejmów, elekcji. Wówczas użyczano sobie wzajemnie tekstów i odpisywano je, a potem przywożono w swoje strony i dalej je powielano trybem sąsiedzkim. Ale właśnie dla potrzeb uczestników tego obiegu „wypączkowal” z niego zupełnie nowy obieg, juz pośredni, korzystający z usług poczty, i to nie jako biernego przekaziciela, ale czynnie: w roli swego rodzaju „wydawcy”.

Oto bowiem poczmistrze niektórych ważniejszych stacji pocztowych zaczęli występować w charakterze przedsiębiorców, posiadających w kraju specjalnych, opłacających to prenumeratorów, którym nadsyłali „gazetki” pisane. Z czasem powstały niezależne od poczty redakcje (na przykład pijara Teodora Ostrowskiego, które jednak nadal z jej usług korzystały). Poczmistrze zatrudniali armie skrybów, którym dyktowano zasadniczy tekst informacyjny gazetki oraz załączniki do nich. Następnie je adresowano i wysyłano pocztą do prenumeratorów. (Nie zawsze sobie uświadamiamy, że gazetki pisane poprzedzały rozwój prasy drukowanej, a następnie prawie do końca XVIII wieku towarzyszyly mu). Dla nas od samej właściwej gazetki ważniejsze są wspomniane załączniki. Znajdowały się w nich czasem dokumenty przytaczane in extenso, ale najczęściej były to utwory literackie, na ogół okolicznościowo-polityczne, które tym sposobem rozchodziły się po całym kraju.

Sprawę tę tutaj tylko sygnalizuję. Ten typ obiegu upowszechnił się ostatecznie dopiero w XVIII wieku. Dokładniej go omówię w następnym rozdziale. Tutaj natomiast chciałbym jeszcze zwrócić uwagę na jedną ważną okoliczność wyróżniającą sarmacką formację kulturową od poprzednich w zakresie statusu rękopisów. Otóż do tej pory obieg tych ostatnich był tylko paralelny w stosunku do obiegu druków. Teraz nabiera także charakteru alternatywnego. Wiąże się to z tym, że dzieła drukowane zaczęły być wiązane ze sferą oficjalności, zaś rękopisy nieoficjalności. Nie bylo jeszcze tego podziału w XVI wieku. Kochanowski fraszki „dobrym towarzyszom gwoli" mógł wydrukować. W stuleciu XVII z reguły fraszki w całości zostawiano rękopisom. Drukowano natomiast literaturę religijną, naukową, ale na przyklad także panegiryki - wręcz nie wypadało oddawać ich adresatowi w rękopisie, wymagały druku. Natomiast z kolei nie wypadało drukować twórczości ludycznej.

I jeszcze jedno: dzieła drukowane zaczęły się cieszyć mniejszym zaufaniem niż rękopisy. Wiązało się to częściowo z tym, że druki podlegały mniejszej lub większej cenzurze, rękopisy nie - ale to tylko jedna z przyczyn. Jawil się rękopis bowiem także jako bardziej autentyczny i z tej przyczyny wiarygodny. To także sprawiało, że w czasach saskich i wczesnostanisławowskich utwór publicystyczny autor wolal „puścić w obieg” (termin ówczesny) w postaci rękopisu, niż oddać do druku.

O poruszonych powyżej sprawach pisałem szerzej przy innych okazjach ${ }^{16}$. Przywołuję je natomiast dla podkreślenia, że tak bogaty w XVII wieku obieg rękopiśmienny literatury był

${ }^{16}$ Zob. J. Maciejewski, Folklor środowiskouy. Sposób jego istnienia, cechy uyodrębniajq̨e (na przykladzie "folkloru" 
z jednej strony kontynuacją wykształconych już w dwóch poprzednich stuleciach form (nie stanowił więc czegoś zaskakującego). Ale z drugiej strony miał swoją specyfikę - wyrastającą z typu kultury, w jakiej się rozwijał — która zdecydowała o jego barwach i jego roli zarówno wówczas, jak i w całokształcie literatury polskiej.

Obieg rękopiśmienny także przez większość XVIII wieku pozostal jedną z podstawowych form rozpowszechniania literatury. Działały w dalszym ciągu jego wykształcone w poprzednim stuleciu formy i modele. Tym się jednak różnił, że rozwinął się i spotężniał obieg pośredni - obieg, który w poważnym stopniu (jeśli nie w większości) korzystał z usług rozwiniętej już w tym czasie instytucji poczty. Korzystano z niej oczywiście od początku istnienia tejże. Zawsze bowiem korespondencji towarzyszyło cytowanie bądź przesyłanie jako załączników do listów tekstów literackich. Przesyłano także osobno rękopisy (jak i — rzecz jasna - książki drukowane). Teraz jednak zwyczaj ten ulegl pewnej konwencjonalizacji, związanej ściśle z rozwojem ówczesnym czasopiśmiennictwa: właśnie rękopiśmiennego. Mianowicie z rozkwitem w XVIII stuleciu wspomnianych już wyżej „gazetek pisanych” tekstów informacyjnych prenumerowanych przez czytelników i rozsyłanych im droga pocztową. Roman Kaleta tak o tym zwyczaju pisze:

Aby zapewnić sobie regularny dopływ świeżych wiadomości ze stolicy, prawie wszyscy magnaci mieszkający na prowincji lub przebywający za granicą, niezależnie od okolicznościowych związków listownych z familią i z wysoko postawionymi osobistościami, opłacali w Warszawie dobrze zorientowanych korespondentów, którzy wysyłali im raz lub dwa razy w tygodniu nowiny gabinetowe i sekrety życia towarzyskiego. Nie tylko bogata szlachta, ale i magistraty znaczniejszych miast Rzeczypospolitej posiadaly w stolicy umówionych pisarzy, którzy im wysyłali listowne gazety. Pisane „famoruchy” prenumerowali również i chętnie czytali ludzie składający tzw. wielki świat warszawski. Pierożek papieru nafaszerowany przez wścibskiego nowiniarza smakował bardziej niż dzienniki drukowane, był „szczególniej szacowny” i większą mu dawano wiarę niż cenzurowanemu „Kurierowi” ${ }^{17}$.

Oczywiście „gazetki pisane”, nie powstały dopiero w XVIII wieku. Jan Lankau początki ich widzi jeszcze w średniowieczu ${ }^{18}$, a rozwinięte formy w wieku XVII, kiedy konkurowały już skutecznie z prasą drukowaną. Zwraca też uwagę, iż nie powstawały one tylko w stolicach: Krakowie a później w Warszawie (jak można by sądzić z cytowanej wyżej wypowiedzi Kale-

szlacheckiego XVII i XVIII wieku), w: idem, Obszary i konteksty literatury, Warszawa 1999, s. 39-55, oraz Sarmatyzm jako formacja kulturowa, w: idem, Dylematy wolności. Zmierzch sarmatyzmu i początki oświecenia w Polsce, Warszawa 1994, s. 199-223.

17 T. Ostrowski, Poufne wieści z oświeconej Warszawy, opr. i wst. R. Kaleta, Wrocław 1972, s. 7.

18 Zob. J. Lankau, Prasa staropolska na tle rozwoju prasy' w Europie 1513-1729, Kraków 1960, s. 53. 
ty). Pisywali je do swych korespondentów także „gazeciarze” - głównie poczmistrze z Gdańska, Torunia, Lwowa ${ }^{19}$. WXVIII wieku miał więc już ten zwyczaj długą tradycję, choć rzeczywiście prawdziwy rozkwit gazetek pisanych — co do tego zgadzają się wszyscy badacze - przypadł właśnie na czasy saskie i stanisławowskie.

Funkcja platnego „gazeciarza” — pisze Jerzy Jackl — wysyłającego z Warszawy na prowincję poufne „nowiny” stała się już w czasach saskich oficjalną kondycją. Zachowały się teksty umów zawieranych między „gazeciarzami” a ich odbiorcami (...). Obok jednostkowych istnialy także gazety pisane „wielonakładowe”, nie różniące się sposobem rozpowszechniania od gazet drukowanych (np. gazety z dystrybucji poczty zamojskiej czy wileńskiej, kopiowane dla wielu adresatów); między poszczególnymi korespondentami i „redakcjami” istniały liczne powiązania i wymiana wiadomości (...); byl to, jak na warunki osiemnastowieczne, „wielki przemysł”, bijący na głowę sprawnością i obfitością informacji prasę drukowaną ${ }^{20}$.

Otóż „przemysł” ten ma swoje znaczenie nie tylko dla obiegu informacji, ale i dla literatury. Gazetkom bowiem wysyłanym do prenumeratorów towarzyszyły zalączniki, i to dwojakiego rodzaju. Jeśli na przykład jakiemuś wydarzeniu dyplomatycznemu towarzyszył list, oświadczenie czy inny dokument, przepisywano go także, zalączano do "gazetki” i wysyłano razem $z$ nią. Ale częściej był to nie dokument, ale utwór literacki - oczywiście $\mathrm{w}$ mniejszym lub większym stopniu dotyczący tegoż wydarzenia. Stanowil on dodatkową ciekawostkę, ale zarazem potwierdzenie wiadomości politycznej czy plotki obyczajowej. Była to więc prawie wyłącznie literatura okolicznościowa, bardzo bogata w XVIII stuleciu. Z zasady była ona rozpowszechniana w ten właśnie sposób i w ogóle nie znała druku. Potwierdzenia tego sposobu jej egzystencji mamy dopiero z okresu konfederacji barskiej i jej okolic, ale wolno sądzić, że już dużo wcześniej uprawiano zwyczaj wysyłania prenumeratorom załączników literackich.

Podstawowym na to dowodem jest tzw. archiwum księcia Ksawerego Saskiego, znajdujące się dziś w zbiorach specjalnych Biblioteki Polskiej w Paryżu. Archiwum to sklada się w swej głównej części z regularnie wysyłanych do Drezna doniesień z Warszawy, pisanych po 1764 r. przez stałego, opłacanego za to korespondenta, niejakiego Heinego. Są one utrzymane w konwencji typowych „gazetek”, przynoszą krótkie relacje o różnych wydarzeniach — także kulturalnych. (Zawierają na przykład swoiste recenzje wszystkich przedstawień teatralnych — bogatą kopalnię wiedzy dla historyków teatru) ${ }^{21}$. Dołączone są do nich (w całości) teksty wszystkich krążących wówczas po Warszawie utworów literackich i publicystycznych, doty-

\footnotetext{
19 Ibidem, s. 198-202.

${ }^{20} \mathrm{~J}$. Jackl - wstęp do wyboru "gazetek pisanych” z Warszawy w czasie konfederacji barskiej. Maszynopis w archiwum Pracowni Literatury Okolicznościowej i Użytkowej Instytutu Literatury Polskiej Uniwersytetu Warszawskiego,

21 Zob. M. Klimowicz, Początki teatmu stanistawowskiego 1765-1773, Warszawa 1965.
} 
czących opisywanych wydarzeń, nawet niekiedy bardzo długich, jak np. dialogi Pię́́ perspektyw ekstraordynaryjnych czy Rozmowa katolika z dysydentem, Pieśn wielkopolskiej konfederacyi, Lament nad Polską, Portret króla polskiego Poniatowskiego itp. Razem ukladają się w jedną z najbogatszych, aktualnie $z$ dziejącymi się wydarzeniami powstającą, antologię literatury okolicznościowej tego okresu.

Heine prawdopodobnie nie miał innych odbiorców poza dworem saskim. Jego „gazetka” należała zapewne do tych, które Jackl określał jako ,jednostkowe”. Ale większość z nich była „wielonakładowa", przy czym także rozsyłała do prenumeratorów - jako załączniki do podstawowych tekstów informacyjnych - utwory literackie, niekiedy bardzo dużych rozmiarów.

Należaly do nich na przykład dwa niezwykle popularne dramaty z czasów konfederacji barskiej: Perekińczyk i Cnota uciemiężona, wolność obarczona. (Powstało w tym okresie więcej dramatów, ale pozostałe nie były tak powszechnie czytane). Dochowało się do naszych czasów kilkaset przekazów rękopiśmiennych tych dwóch utworów, co szacunkowo dowodzi, że łączny ich nakład musiał wynosić co najmniej kilka tysięcy egzemplarzy. Większość z nich wykazuje bardzo podobne blędy, sugerujące, iż ci, którzy je przepisywali, nie czytali tego, co już zanotowali. Powtarzalność ich każe zastanowić się nad przyczynami tego, a zatem i nad ówczesną techniką ich powielania.

Otóż redaktorzy „gazetek” „wielonakładowych” wydawali je w ten sposób, iż zatrudniali kilkudziesięciu albo i więcej skrybów. Przygotowany tekst był im dyktowany. Przepisywali go szybko, nie mając czasu zastanowić się, czy dobrze zostal zrozumiany, bo dyktujący już odczytywał dalsze jego fragmenty ${ }^{22}$. Stąd obecność w nich blędów, i to powtarzających się co stanowi wielkie utrudnienie dla współczesnego edytora.

W ten właśnie sposób rozpowszechniano większość okolicznościowej literatury politycznej, niezwykle bogatej w XVIII wieku, zwlaszcza w czasach konfederacji barskiej. Rozpowszechniano także publicystykę, a nawet niektóre dokumenty polityczne. Przykładem może być list do Generalności biskupa Adama Krasińskiego, protestujący przeciwko ogłoszeniu przez nią bezkrólewia. Krasińskiemu zależało na tym, aby dotarł on nie tylko do adresatów, ale i do możliwie najszerszej publiczności, wobec czego „puścil go w obieg” — oczywiście rękopiśmienny.

Czy nie mógł go opublikować drukiem? Oczywiście mógł: miał i pieniądze i dostęp do prasy, przebywal za granica. Ale i w kraju nie mialby trudności. Wszystkie manifesty i uniwersały konfederacji ukazywały się w formie druczków ulotnych. Taka byla konwencja ówczesnej kultury: rzecz oficjalną, dostojną należało drukować. Ale bardziej osobistą, mniej oficjalną lepiej było puścić w rękopiśmienny obieg. Raczej na taką formę oczekiwali odbiorcy, byla dla nich bardziej wiarygodna. Wydoskonalone już techniki powielania tekstu zapewniały nie gorsze od druku jego rozpowszechnienie. List biskupa Krasińskiego dotarł do naszych

22 Informację o sposobach powielania omawianych tekstów zawdzięczam Jerzemu Jacklowi. 
czasów także w kilkuset przekazach. Uwaga ta dotyczy także utworów literackich. Z powodzeniem mogły być one drukowane, ale konwencje kultury schyłkowego sarmatyzmu łączyły je z obiegiem rękopiśmiennym. Tak je też rozpowszechniano.

Pisałem dotąd o obiegu rękopiśmiennym korzystającym z usług poczty. Ale - jak wspomniałem wyżej - w XVIII wieku nie zamarły i inne, można powiedzieć tradycyjne, bezpośrednie obiegi rękopisów: rodzinny, sąsiedzki, dworski (na przykład w Puławach, Łańcucie, Tulczynie). Już w czasach stanisławowskich na krótko doszedł jeszcze jeden, który można by nazwać kawiarniano-środowiskowym, obecnym zwłaszcza w Warszawie, w ramach którego krążyły wiersze obyczajowe i polityczne, między innymi Kajetana Węgierskiego, Jana Czyża, Jana Ancuty i licznych anonimów. Obieg pośredni, dotąd omawiany, niewątpliwie w tym stuleciu dominował, ale tamte walnie go uzupełniały. Razem sprawiały, że większość tego stulecia, podobnie jak poprzednie, można nazwać „wiekiem rękopisów”; że nie tylko wiersze czy drobne utwory prozatorskie, ale i obszerne dzieła, jak wspomniane wyżej dramaty czy powieść Saxe galant (o miłostkach Augusta II), rozchodziły się w formie rękopiśmiennej co nie przeszkadzało ich popularności.

Ale w tymże stuleciu - choć dopiero pod jego koniec - nastąpiło dość gwałtowne załamanie się tego typu praktyk. Docieranie w głąb społeczeństwa bardzo dotąd elitarnej kultury oświecenia, udoskonalenie i potanienie druku, sprawiły, że ten ostatni zacząl coraz śmielej wkraczać na tereny zarezerwowane dotąd dla obiegu rękopiśmiennego. Przestał też być traktowany jako coś oficjalnego, dostojnego. Okolicznościowa literatura polityczna czasów Sejmu Czteroletniego rozchodzi się już zarówno w formie rękopisów, jak i ulotnych druków. Wyłącznie w formie drukowanej zaczynają publicznie egzystować większe utwory literackie: dramaty, powieści, zbiory wierszy - także okolicznościowych. I choć jeszcze przez cały wiek XIX przepisuje się także ręcznie literaturę, stanowi ta forma wąski margines w sposobach jej rozpowszechniania. 